DOI https://doi.org/10.18551/rjoas.2020-09.07

\title{
MEASURING CUSTOMER SATISFACTION AT THE GO-RIDE SERVICE OF BALI, INDONESIA
}

\author{
Trisnayanti Gusti Ayu Putu*, Abiyasa Agus Putu \\ Master's Study Program of Management, Undiknas Graduate School, Indonesia \\ *E-mail: gek.trisna85@gmail.com
}

\begin{abstract}
The transportation industry is growing very rapidly. Transportation has become a basic necessity for the community. With advances in information and communication technology, currently motorbikes as public transportation have been manifested in the form of online motorcycle taxis, one of which is GO-JEK. GO-JEK has not been able to divert the use of private vehicles from residents. GO-JEK users for GO-RIDE service are dominated by local tourists and migrants. This can be caused by the services provided by GO-JEK have not fully attracted customers to use the services provided. Customers are not very satisfied with the services provided thus leading to distrust. Therefore, this study will examine customer satisfaction of GO-JEK, especially GO-RIDE in Bali to find out how the service quality and its usefulness for the local community. This research is uses qualitative and quantitative approaches. The method in this study used field analysis with the Miles and Huberman model. The technique of checking the validity of the data used in this study was the triangulation technique. The statistical analysis used to support this research is multiple linear regression analysis. Based on the results of the interviews conducted, it was found that three factors affect customer satisfaction, namely price perception, service quality and brand image. Perception of price, service quality, and brand image have a positive and significant effect on Go-Ride customer satisfaction either partially or simultaneously. Suggestions that can be given in connection with the results obtained for consideration, namely marketers must understand the market and the needs and desires of customers. Next, marketers design customer driven marketing strategies with the aim of acquiring, retaining and growing targeted customers. Furthermore, marketers build marketing programs that deliver truly superior value. Finally, management must build profitable customer relationships, and create customer satisfaction.
\end{abstract}

\section{KEY WORDS}

Online transportation, satisfaction, service quality, price perception, brand image.

The transportation industry is currently growing very rapidly. Every year there is an increase in the number of vehicles, both passenger cars, buses, cargo cars, and motorbikes. Of the four modes of transportation, the increase in the number of motorbikes year to year is the highest. Aziah (2018) states that transportation is a means commonly used to transport goods or people from one place to another. Online transportation is an example of application-based technology development that was welcomed quite well at the beginning of its appearance because it was considered one of the best innovations, with a good transportation system, which would facilitate the mobility of the population and other resources, so that it could support the economic growth of people in urban and rural areas. Therefore, the government needs to provide a transportation system that allows transportation by land, water and air to reach all parts of Indonesia (Jura et al., 2016; Kurnia, 2017). Advances in information and communication technology, currently motorbikes as public transportation have been manifested in the form of online motorcycle taxis, one of which is GO-JEK. GO-JEK is an application that serves transportation via ojek services and is a medium of contact for passengers and drivers (Junior, 2017). According to Tumewe (2018) Go-Jek is the pioneer of online motorcycle taxis in Indonesia and is the largest for now, and is under the company PT. Go-Jek Indonesia. As stated by Syahbandi (2012), in business competition, marketers must be able to satisfy all customer needs and desires with 
demands that change from time to time. Satisfying the needs and gaining customer trust can be done by providing the best service for consumers. Panjaitan and Yuliati (2016) in their research state that service quality that gets a positive value and has a good impression will increase customer satisfaction. Where the factors that most influence customer satisfaction are the responsiveness of service providers, followed by reliability, assurance, and empathy (Wijaya, 2017). In running the Go-Ride business, Go-Jek really depends on the satisfaction of its customers. Consumer satisfaction itself is influenced by many things, but based on the initial survey there are three main variables that affect customer satisfaction, namely price perception, service quality and brand image. From the results of the pre-survey of 30 respondents, information was obtained that some customers showed dissatisfaction with the service, price, and brand image problems with GO-RIDE from Gojek.

The pre-survey results show 3 variables that affect GO-RIDE customer satisfaction, namely price perception, service quality, and brand image. If you look at the price perception variable, customers give answers that $66.7 \%$ are not satisfied and $33.3 \%$ are satisfied. This is because prices often change at certain hours. Although prices change with changes in fuel prices and during working hours, customers feel the price of delivery services is quite burdensome for those who wish to travel short distances. From the service quality variable, there were $60 \%$ unsatisfied and $40 \%$ satisfied answers. This result is caused by customers who often complain about the late arrival time of drivers who are not in accordance with the schedule and drivers' unpreparedness in finding location access. Brand image is the variable that gets the most dissatisfied results, namely $70 \%$ and the satisfaction level is only $30 \%$. There are various reasons for this to happen. The main reason is that the image given by GO-RIDE from Gojek is the same as other public transportation in Denpasar, such as the example of vehicle fumes that cause air pollution, and sometimes passengers find drivers who drive not according to the rules, like smoking when driving a vehicle.

Providing the best service to passengers is something that must be considered by public transport service providers. The services in question include starting from offering products / services, services when providing services, services for risks that occur when providing services, and other services (Agustinus, 2017; Assauri, 2015). This satisfaction can be seen from the behavior of consumers who use return services continuously which will lead to loyalty. However, in reality what is happening in Bali at this time, GO-JEK is still unable to shift the use of private vehicles from local residents. GO-JEK service users for GO-RIDE are dominated by local and foreign tourists. This can be caused by the services provided by GOJEK not yet fully attracting customers to use the services provided and customers are not too satisfied with the services provided. So that customers do not fully believe in using GO-JEK services continuously. Therefore, this study will examine more deeply the customer satisfaction of GO-JEK, especially GO-RIDE in Bali to find out how its service quality and benefits for the local community.

Hypotheses:

- H1: Perceived price has a positive influence on customer satisfaction;

- H2: Service quality has a positive influence on customer satisfaction;

- H3: Brand image has a positive influence on customer satisfaction;

- H4: Perceived price, service quality, and brand image together have a positive influence on customer satisfaction.

\section{METHODS OF RESEARCH}

This study uses two approaches, namely a quantitative approach with survey methods and a qualitative approach with interview methods. According to Prof. Dr. Sugiyono (2008) states that these two methods can be used together or combined with several notes, namely that they are used on the same research object, and are used interchangeably. Sampling in this study was carried out by purposive sampling technique, data collection techniques in this study used triangulation methods and qualitative data analysis. In this study, the results that the researcher wants to get are to find out how customer satisfaction is at GO-RIDE services in Bali. Tringulation is a method in qualitative research to combine methods (method 
triangulation), data sources (data triangulation), researchers (investigator triangulation), as well as perspectives and theories (theoretical triangulation) (Yin, 1994). The research object is GO-RIDE and the research subject is the resource person or respondent. The primary data collection method was carried out by direct interviews with GO-RIDE riders and service customers and by providing research instruments in the form of offline questionnaires to users of GO-RIDE services in Denpasar and Badung areas. Statistical analysis completed using SPSS 23.

\section{RESULTS OF STUDY}

Discussion on Go-Jek Go-Ride Service User Satisfaction in the Bali Region. Based on the results of interviews with Go-Ride users in Bali, three factors can be formulated that affect the satisfaction of Go-Ride service users in the Bali region. The first factor that affects customer satisfaction is service quality. Lupiyoadi and Hamdani (2009: 65) suggest that service quality has an effect on customer satisfaction, where good service has a greater impact on customer satisfaction. Even though service / service is an intangible item, service can be assessed based on someone's experience and reasoning. Service quality can affect consumer satisfaction because of the interaction between consumers and the company. In accordance with the concept of customer satisfaction, that customer satisfaction can be achieved if the performance or results felt are in accordance with consumer expectations. So, whether or not the services provided by the company greatly affect customer satisfaction.

The second factor that affects customer satisfaction is price perception. According to Kotler and Keller (2007: 156) price is the amount of money (possibly several items weighed) needed to obtain several combinations of a product and service that accompanies it. Price is something that can be controlled and determines whether or not a product is accepted by consumers. The price depends solely on company policy but of course taking various things into account.

The third factor that affects customer satisfaction is brand image. Image according to Peter and Olson (2000: 248-249) is what consumers think about a product. This includes perceptions and attitudes based on reactions and stimuli relating to the company received through the five senses. Image is the way a person or group views an object. The company must re-survey the public periodically to see if the activities carried out by the company have improved its image.

Customer satisfaction is a very important factor for the existence, continuity and development of the company. Today many companies are increasingly understanding the importance of customer satisfaction and implementing strategies to provide satisfaction to their customers. According to Engel, et al., (1990) in Tjiptono (2002: 146), customer satisfaction is a post-purchase evaluation where at least it gives the same or exceeds customer expectations. Meanwhile, dissatisfaction arises when the results obtained do not meet customer expectations. According to Buttle (2007: 28) consumer satisfaction has a big impact on the company. By keeping and satisfying current customers is much easier than constantly trying to attract or prospect new customers, the cost of retaining customers is less than the cost of finding new customers.

Service quality, price perception, and brand image are important things that can affect customer satisfaction. Parasuraman, et al. (1988: 118) states that high service quality results in high customer satisfaction as well. If the service received or perceived by the customer matches or even exceeds the customer's expectation, the service is considered to be of high quality and satisfactory. The second factor that affects customer satisfaction is price perception. If the price set by a company is not in accordance with the benefits of the product, it can reduce the level of customer satisfaction, and vice versa, if the price set by a company is in accordance with the benefits received, it will increase customer satisfaction. Brand image can also affect customer satisfaction because a good image of an organization will have a beneficial impact, while a bad image will be detrimental to the organization. A good image gives a positive impression to an organization, so it can create satisfaction. 
Respondent Characteristics. Respondents of this research are residents of Bali Province who have used the services of Gojek in the last 1 year with a minimum age of 17 years because they are considered adults and are able to wisely answer the questions asked in interviews and questionnaires. The number of female respondents was greater, namely by 59 percent. This means that women are more likely to use Go-Ride services than men. The number of respondents who have the latest education of bachelor's degree and master's degree is more, which is 26 percent, this means that respondents who have the latest good education tend to choose to use Go-Ride compared to other transportation. The largest number of respondents who have civil servant jobs is 33 percent, this means that respondents who have jobs as civil servants tend to choose Go-Ride as a means of transportation. The number of respondents who have an income of around Rp. 6,000,001 Rp. 9,000,000 has the largest number, namely 37 percent, this means that respondents who have an income of Rp. 6,000,001 - Rp. 9,000,000 tend to choose Go-Ride as one of their means of transportation.

Table 1 - Results of Multiple Regression Analysis

\begin{tabular}{|c|c|c|c|c|c|c|c|c|c|c|c|c|c|}
\hline & \multirow{2}{*}{ Model } & \multicolumn{2}{|c|}{$\begin{array}{l}\text { Unstandardized } \\
\text { Coefficients }\end{array}$} & \multirow{2}{*}{$\begin{array}{c}\begin{array}{c}\text { Standardized } \\
\text { Coefficients }\end{array} \\
\text { Beta }\end{array}$} & \multirow{2}{*}{$\mathrm{t}$} & \multirow{2}{*}{ Sig. } & \multicolumn{2}{|c|}{$\begin{array}{c}95.0 \% \\
\text { Confidence } \\
\text { Interval for B }\end{array}$} & \multicolumn{3}{|c|}{ Correlations } & \multicolumn{2}{|c|}{$\begin{array}{l}\text { Collinearity } \\
\text { Statistics }\end{array}$} \\
\hline & & B & $\begin{array}{l}\text { Std. } \\
\text { Error }\end{array}$ & & & & $\begin{array}{l}\text { Lower } \\
\text { Bound }\end{array}$ & $\begin{array}{l}\text { Upper } \\
\text { Bound }\end{array}$ & $\begin{array}{l}\text { Zero- } \\
\text { order }\end{array}$ & Partial & Part & Tolerance & VIF \\
\hline \multirow{4}{*}{1} & (Constant) & $-0,153$ & 1,769 & & $-0,087$ & 0,931 & $-3,665$ & 3,359 & & & & & \\
\hline & $\mathrm{X} 1$ & 0,267 & 0,113 & 0,285 & 2,369 & 0,020 & 0,043 & 0,490 & 0,852 & 0,235 & 0,111 & 0,153 & 6,550 \\
\hline & $\mathrm{X} 2$ & 0,323 & 0,067 & 0,567 & 4,806 & 0,000 & 0,190 & 0,457 & 0,868 & 0,440 & 0,226 & 0,159 & 6,298 \\
\hline & X3 & 0,191 & 0,074 & 0,130 & 2,568 & 0,012 & 0,043 & 0,339 & 0,411 & 0,253 & 0,121 & 0,864 & 1,157 \\
\hline
\end{tabular}

Source: Data processed, 2020.

Table 2 - Results of the Analysis of the Coefficient of Determination

\begin{tabular}{|c|c|c|c|c|c|c|c|c|c|c|}
\hline \multicolumn{11}{|c|}{ Model Summary ${ }^{b}$} \\
\hline \multirow[b]{2}{*}{ Model } & \multirow[b]{2}{*}{$\mathrm{R}$} & \multirow[b]{2}{*}{$\begin{array}{c}\mathrm{R} \\
\text { Square }\end{array}$} & \multirow[b]{2}{*}{$\begin{array}{l}\text { Adjusted R } \\
\text { Square }\end{array}$} & \multirow{2}{*}{$\begin{array}{l}\text { Std. Error of the } \\
\text { Estimate }\end{array}$} & \multicolumn{5}{|c|}{ Change Statistics } & \multirow{2}{*}{$\begin{array}{l}\text { Durbin- } \\
\text { Watson }\end{array}$} \\
\hline & & & & & $\begin{array}{c}\text { R Square } \\
\text { Change }\end{array}$ & F Change & df1 & df2 & $\begin{array}{c}\text { Sig. F } \\
\text { Change }\end{array}$ & \\
\hline 1 & $.888^{\mathrm{a}}$ & 0,788 & 0,781 & 2,05720 & 0,788 & 119,014 & 3 & 96 & 0,000 & 2,142 \\
\hline \multicolumn{11}{|c|}{ a. Predictors: (Constant), X3, X2, X1 } \\
\hline b. Dep & ndent $\mathrm{V}$ & ariable: $Y$ & & & & & & & & \\
\hline
\end{tabular}

Source: Data processed, 2020.

Table 2 states that the $R$ square $\left(R^{2}\right)$ number is 0.788 which explains that the independent variables are able to explain the dependent variable by $78.8 \%$. The remaining $21.2 \%$ explain other variables not examined in this study.

\section{DISCUSSION OF RESULTS}

The Effect of Price Perception on Customer Satisfaction. The price perception variable has a positive and significant effect on customer satisfaction, this means that the better a customer perceives the price offered by Go-Ride services from Gojek, the more customer satisfaction increases.

Customer satisfaction is influenced by price perception. When consumers assume the price of a product or service is in accordance with the benefits obtained, it will provide satisfaction. Price is an important part of the marketing process because it is included in the marketing mix. This is in line with the research of Shandy lbnu Zakaria (2013) entitled Analysis of Factors Affecting Customer Satisfaction of Trans Jogja Bus Transportation Service Users, which concludes that the variables of service quality and price perception simultaneously have a significant effect on consumer satisfaction for Trans Jogja Bus users.

The results of this study are in accordance with previous research, namely according to Hermann et al. (2007) states that prices can affect customer satisfaction, where prices vary according to type and function. Consuegra et al. (2007), Bei and Yu-Ching (2001), Martin et al. (2007) found that there is a positive relationship between price fairness and customer 
satisfaction. The same thing was done by oteh Kurniawan et al. (2007) that the price has an effect on repurchase interest. The price offered to customers can also affect customer interest in repurchasing the product.

The Effect of Service Quality on Customer Satisfaction. Service quality variables have a positive and significant effect on customer satisfaction; this means that the better the quality of service provided by Go-Ride service providers, the greater the satisfaction of these customers.

Customer satisfaction is influenced by service quality. This is based on the fact that consumers consider or assess the quality of the product or service. When the quality of service provided by the Trans Jogja bus service provider is good, consumers or customers will be satisfied. This also means that if the quality of service is higher, it will result in higher customer satisfaction. This study supports the results of research conducted by Ade Duana Pratiwi (2012) with the title The Effect of Service Quality and Ticket Prices on Customer Satisfaction of Executive Class Kaligung Mas Train Service Users at PT. KAI DAOP 4 Semarang, shows that service quality and price have a positive and significant effect on user satisfaction of the Executive Class Kaligung Mas train service. The results of this study are in accordance with previous research, namely according to Mulyono (2007) and Puspitasari (2011) which states that service quality has a significant positive effect on customer satisfaction, so it can be concluded that the higher the service quality, the higher the customer satisfaction.

Another study conducted by Wibowo, et al (2013) also states that service quality has a positive effect on customer satisfaction. This positive effect indicates that the higher the service quality received by the respondent will result in high customer satisfaction. Likewise, research conducted by Ramadhan and Santosa (2017) and Putro et al. (2014) stated that service quality is proven to have a significant and positive effect on customer satisfaction. This means that the research states that if service quality is improved, customer satisfaction will also increase.

The Effect of Brand Image on Customer Satisfaction. The brand image variable has a positive and significant effect on customer satisfaction, the better the Go-Ride image, the higher Go-Ride customer satisfaction. Customer satisfaction is influenced by brand image. A good brand image attached to a product or service is able to provide satisfaction to customers through customer psychology. Customers will feel satisfied when the brand image of the product used is good, famous, and easy to remember. The more often someone receives positive things about a product, the higher the sense of belonging to a product. This is in accordance with the research conducted by Dian Balqis (2009) which states that brand image has a significant effect on customer satisfaction. Brand image is a strong sub variable within the company and is very important in purchasing decisions for customers (Nigam et al., 2011). Brand image recommendations that consumers have will help consumers in making purchase decisions (Arslan, 2014). Research by Nila (2012) found that brand image has a significant effect on consumer satisfaction for Canon DSLR cameras, and states that consumers are satisfied with brand image, which means that companies must be able and strive to improve how the product benefits, the ease of obtaining the product, a brand that is easily recognizable and according to consumer needs, which later makes consumers more satisfied and ignores other product offerings or loyal to the products used. Research by Kurniawati et al. (2014) found that brand image has a significant effect on satisfaction. The benefits provided by a brand can satisfy consumer needs and desires. Research by Pusparani and Rastini (2014) found that consumer satisfaction is formed by brands having a positive image, brands having distinctive features and well-known product brands. The better the brand image in the minds of consumers, the consumers will be satisfied with using the product. Research by Susanti and Wardana (2015) found that brand image has a positive significant effect on customer satisfaction of The Body Shop's green cosmetic products. This means that the more positive perceptions of the brand image by customers, the more satisfaction felt by these customers. Research by Sulistiyanto (2015) found that brand image has a positive and significant effect on customer satisfaction at Dela Pharmacy in Semarang, so that the better the brand image, the customer satisfaction will also increase. 
The Effect of Price Perception, Service Quality, and Brand Image on Customer Satisfaction. From the test results obtained the calculated $F$ value of 119.014 with a significance of 0.000 with a significance value less than $0.05(p<0.05)$, then this means that perceived price, service quality and brand image together have an effect on satisfaction. customers, this means that the better the perception of price, service quality, and brand image felt by customers, the more satisfaction of Go-Ride customers in Bali will increase.

\section{CONCLUSION AND SUGGESTIONS}

Looking at the results and discussion in the previous chapter, GO-JEK's position as an online motorcycle taxi began to be threatened as competition began to rise. GO-JEK must be able to react and continue to innovate so as not to lose customers. In business competition, marketers must be able to satisfy all the needs and wants of customers with demands that change from time to time. Satisfying the needs and gaining customer trust can be done by providing the best service for consumers. The services in question include starting from offering products / services, services when providing services, services for risks that occur when providing services, and other services. This satisfaction can be seen from the behavior of consumers who use return services continuously which will lead to loyalty. However, in reality what is happening in Bali at this time, GO-JEK is still unable to shift the use of private vehicles from local residents. GO-JEK service users for GO-RIDE are dominated by local and foreign tourists. This can be caused by the services provided by GO-JEK not yet fully attracting customers to use the services provided and customers are not too satisfied with the services provided. So that customers do not fully believe in using GO-JEK services continuously. Based on statistical calculations the conclusion that can be drawn is that the perception of price, service quality, and brand image has a positive and significant effect on Go-Ride user satisfaction from Go-Jek in Bali, both partially and simultaneously.

Suggestions that can be given in connection with the results obtained for consideration, namely marketers must understand the market and the needs and desires of customers. Next, marketers design customer-driven marketing strategies with the aim of acquiring, retaining and growing targeted customers. Furthermore, marketers build marketing programs that deliver truly superior value. Finally, management must build profitable customer relationships, and create customer satisfaction.

\section{REFERENCES}

1. Ade, Duana Pratiwi and Sutopo .2012. Pengaruh Kualitas Layanan and Harga Tiket Terhadap Kepuasan Pelanggan Pengguna Jasa Kereta Api Kaligung Mas Kelas Eksekutif Pada Pt. Kai Daop 4 Semarang. Jurnal Manajemen.Volume, Halaman 267-273. Universitas Diponegoro. Semarang.

2. Arslan, M. And Zaman. R. 2014. Impact of Dividend Yield and Price Earnings Ratio on Stock Return. Journal of Finance And Accounting. 5(19), 1-8.

3. Assauri, Prof. Dr. Sofjan Mba. 2015. Manajemen Pemasaran. Pt Raja Grafindo Persada.

4. Fandy Tjiptono. 1997. Strategi Pemasaran. Edisi 1.Penerbit Andi.Yogyakarta.

5. Ferdinand A. 2002. Structural Equation Modelling Dalam Peneltian Manajemen.

6. Hermann, Andreas, Lan Xia, Kent B. Monroe, And Frank Huber. 2007. The Influence of Price Fairness on Customer Satisfaction: An Empirical Test in the Contect of Automobile Purchases. Journal of Product And Brand Management, Vol. 16 No. I, Pp. 49-58.

7. Kurnia, R. 2017. "Hadir Di Manado, Transportasi Online". Http:// Www.Ojek Online Gojek Membuat Resah Ojek Konvensional. (Diakses Senin, 7 November 2019).

8. Kurniawan, Iwan, Suryono Budi Santoso, Bambang Munas Dwiyanto. 2007. Analisis Faktor-Faktor Yang Mempengaruhi Minat Beli Ulang Produk Serta Dampaknya Terhadap Loyalitas Pelanggan (Studi Kasus Pada Produk Sakatonik Liver Di Kota Semarang). Jurnal Studi Manajemen \& Organisasi, Vol. 4 No. 2, Pp: 20-29.

9. Kurniawati, D., Suharyono. 2014. Pengaruh Citra Merek and Kualitas Produk Terhadap Kepuasan and Loyalitas Pelanggan. Jurnal Administrasi Bisnis, 14(2). 125-132. 
10. Martin-Consuegra, D., Molina, A. And Esteban, A. 2007. An Integrated Model of Price, Satisfaction, And Loyalty: An Empirical Analysis In The Service Sector. Journal of Produk \& Brand Management, Vol. 16 No. 7, Pp: 459-468.

11. Mulyono, Bayu Hadyanto. 2007. Analisis Pengaruh Kualitas Produk and Kualitas Layanan Terhadap Kepuasan Konsumen (Studi Kasus Pada Perumahan Puri Mediterania Semarang). Jurnal Studi Manajemen \& Organisasi, Vol. 4 No. 2, Pp: 91-100

12. Murwanti, Sri, and Anggrahini Panca P. 2017. Pengaruh Kualitas Pelayanan and Promosi Terhadap Minat Beli Ulang Jasa Service Motor Dengan Kepuasan Pelanggan Sebagai Variabel Mediasi (Studi Pada Bengkel Motor Ahass Cabang Ums). Seminar Nasional Riset Manajemen \& Bisnis, Pp:207-227.

13. Nigam, A., and Kaushik, R. 2011. Impact of Brand Equity on Costomer Purchase Decisions: An Empirial Investigation with Spesial Reference To Hatchback Car Owners In Central Harayana. Ijcem International Journal of Computational Engineering and Management, 12, $121-128$.

14. Nila Kasuma Dewi, Gus Andri, and Sepris Yonaldi. 2012. Pengaruh Iklan, Citra Merek, and Kepuasan Konsumen Terhadap Loyalitas Konsumen Dalam Menggunakan Vaseline Hand and Body Lotion. Di Kota Padanv (Studi Kasus Di Pt. Unilever Cabang Padang). Jurnal Manajemen and Kewirausahaan. 3(2), 1253-1266.

15. Panjaitan, Januar Efendi and Yuliati, Ai Lili. 2016. Pengaruh Kualitas Pelayanan Terhadap Kepuasan Pelanggan Pada Jne Cabang Bandung. Jurnal Manajemen. Vol. 11. No. 2. 265-289.

16. Pratiwi, A.A. Manik and Kesumadewi, Putu Diah. 2017. Keberadaan Transportasi Online Dalam Industri Pariwisata Bali. Seminar Nasional Sains and Teknologi. Denpasar.

17. Pusparani, Putu Ayu Yulia and Ni Made Rastini. 2014. Pengaruh Kualitas Produk and Citra Merek Terhadap Kepuasan Konsumen and Loyalitas Pelanggan Kamera Canon Digital Single Lens Reflex (Dslr) Di Kota Denpasar. Ejurnal Manajemen Universitas Udayana, 3(5), 1311-1319.

18. Puspitasari, Agnes Niken and Ferdinand, Augusty Tae. 2011. Analisis Pengaruh Kualitas Produk and Kualitas Pelayanan Terhadap Kepuasan Pelanggan Untuk Mendorong Minat Beli Ulang (Studi Pada Pengguna Nokia Di Semarang). Universitas Diponegoro.

19. Putro, Shandy Widjoyo, Prof. Dr.Hatane Semuel, Ms., and Ritzky Karina M.R. Brahmana, S.E., M.A. 2014. Pengaruh Kualitas Layanan and Kualitas Produk Terhadap Kepuasan Pelanggan and Loyalitas Kosnumen Restoran Happy Garden Surabaya. Jurnal Manajemen Pemasaran, Vol. 2 No. 1, Pp: 1-9.

20. Ramadhan, A., G., and Santosa, S., B. 2017. Analisis Pengaruh Kualitas Produk, Kualitas Pelayanan, and Citra Merek Terhadap Minat Beli Ulang Pada Sepatu Nike Running Di Semarang Melalui Kepuasan Pelanggan Sebagai Variabel Intervening. Diponegoro Journal Of Management, Vol. 6, No. 1, Pp: 1-12

21. Shandy, Ibnu Zakaria .2013. Analisis Faktor-Faktor Yang Mempengaruhi Kepuasan Konsumen Terhadap Pengguna Jasa Transportasi Bus Trans Jogja.Skripsi S1. Fakultas Ekonomika and Bisnis. Universitas Diponegoro. Semarang.

22. Sugiyono. 2008. Metode penelitian kuantitatif, kualitatif, and R\&D. Alfabeta: Bandung.

23. Sulistiyanto, F.X and Euis Soliha, Pengaruh Persepsi Harga, Citra Perusahaan and Citra Merek Terhadap Kepuasan and Loyalitas Pelanggan Pada Apotek "Dela" Semarang. Simposium Prosiding Seminar Nasional and Call for Paper Kinerja Perbankan, Bisnis and Ekonomi Indonesia Menghadapi Asean Economic Community 2015, 2016.

24. Susanti, Ni Putu Hani and I Made Wardana. 2015. Pengaruh Kualitas Produk and Citra Merek Terhadap Kepuasan and Loyalitas Pelanggan Pada Produk Kosmetik Hijau Merek The Body Shop. E- Jurnal Manajemen Universitas Udayana, 4(5), 622-636.

25. Syahbandi. 2012. Implementasi Green Marketing Melalui Pendekatan Marketing Mix, Demografi and Pengetahuan Terhadap Pilihan Konsumen (Studi the Body Shop Pontianak). Jurnal Ekonomi, Bisnis, and Kewirausahaan. Volume 3 (1). Hal. 68-86.

26. Yin, K. (1994), Case study research: design and methods, Sage publications, Newbury park, California. 